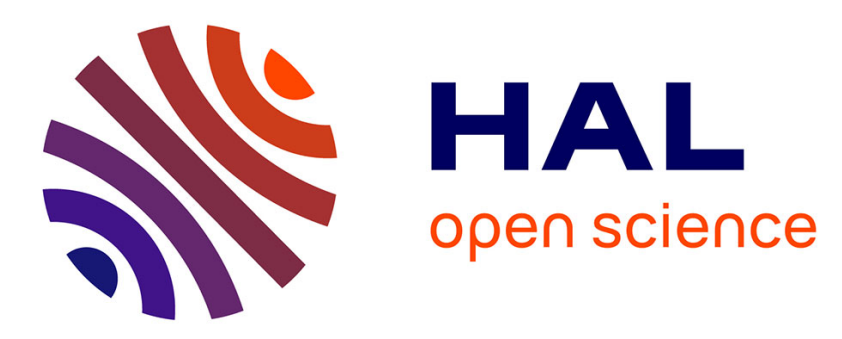

\title{
Plasma applications in microalgal biotechnology
}

Anh Dung Nguyen, Matteo Scarsini, Fabienne Poncin-Epaillard, Olivier Noel, Justine Marchand, Benoît Schoefs

\section{To cite this version:}

Anh Dung Nguyen, Matteo Scarsini, Fabienne Poncin-Epaillard, Olivier Noel, Justine Marchand, et al.. Plasma applications in microalgal biotechnology. Agritech: Innovative Agriculture Using Microwaves and Plasmas Subtitle (if applicable): Thermal and Non-Thermal Processing, In press. hal-03367760

\section{HAL Id: hal-03367760 https://hal.science/hal-03367760}

Submitted on 6 Oct 2021

HAL is a multi-disciplinary open access archive for the deposit and dissemination of scientific research documents, whether they are published or not. The documents may come from teaching and research institutions in France or abroad, or from public or private research centers.
L'archive ouverte pluridisciplinaire HAL, est destinée au dépôt et à la diffusion de documents scientifiques de niveau recherche, publiés ou non, émanant des établissements d'enseignement et de recherche français ou étrangers, des laboratoires publics ou privés. 
Plasma applications in microalgal biotechnology

Anh Dung NGUYEN ${ }^{1,2,3}$, Matteo SCARSINI ${ }^{2,3}$, Fabienne PONCIN-EPAILLARD $^{1}$, Olivier NOEL $^{1}$, Justine MARCHAND ${ }^{2}$, Benoît SCHOEFS ${ }^{2}$

${ }^{1}$ Institut des Molécules et Matériaux du Mans (IMMM)—UMR 6283 CNRS, Le Mans Université, Le Mans, France

${ }^{2}$ Metabolism, Engineering of Microalgal Molecules and Applications (MIMMA), Mer Molécules Santé, IUML - FR 3473 CNRS, Le Mans University, Le Mans, France

\begin{abstract}
Microalgae are very important organisms for the biosphere because they are at the basis of most of the food chains. Some taxa can also bloom and release dangerous toxins in the environment. They are also very promising for industrial applications in various sectors, including food, feed, pharmaceutical, wellness, energy, building, space, water treatment, biosensing, biotechnology etc. The development of these applications require in many cases the optimization of processing steps. Plasma technology has been already applied on biomolecules, proteins, enzymes, peptides in the biomedical field, for the preparation of bioactive, antifouling surfaces of biomaterials. Nowadays, the research prospective deals with the agriculture domain in the purpose of cleaning, sterilizing or fertilizing the soil. However, plasma technology could also be explored in the case of bioenergetic cells where the plasma chemistry enhances bioadhesion and, bioproduction without destroying the microalgae. This chapter gives illustrations on this new application of plasma technology.
\end{abstract}




\section{Introduction}

\subsection{The microalgal world}

Microalgae are eukaryotic unicellular or colonial eukaryotic microorganisms differing from cyanobacteria, which are prokaryotic, by the presence of a nucleus and semi-autonomous organelles. In this chapter, both types of organisms will be designated as microalgae. Microalgae represent a polyphyletic group. They differ by the type of cell wall, pigment composition and metabolism. Being photosynthetic, microalgae contribute to half of the world's oxygen emission and carbon dioxide capture. The generated biomass plays a significant role in the benthic food web because they are enriched in several key ingredients such as vitamins, polyunsaturated fatty acids, magnesium, iron and calcium, antioxidants and other biologically active compounds (Mimouni et al., 2012). Thanks to their powerful adaptive capacity to stress conditions, they have colonized every type of ecological niche (Schoefs et al., 2020, Hopes and Mock, 2015). Consequently, they are abundantly found in rivers, oceans, lakes, sea and moist-soil. Beside their natural content made using the inorganic capture carbon, microalgae can take up, store or transform other inorganic forms of elements such as metals (Masmoudi et al., 2013)).

\subsection{Microalgae are usually developing in unfavorable environment}

The environment is usually rather poor in crucial elements for cell development (Coale et al., 1996) and therefore microalgae develop in unfavorable conditions. Fortunately, the complex evolutionary story of microalgae resulted in organisms exhibiting a tremendous metabolic flexibility (Parker et al., 2008, Hopes and Mock, 2015). This includes the reorientation of the carbon metabolism toward the accumulation of energy inside intracellular compounds such as 
lipids or carbohydrates (Heydarizadeh et al., 2019). Exploiting all of these possibilities perfectly, microalgae are able to occupy every type of ecological niche as well as degraded environments such as those enriched in nitrogen, phosphorus, and other nutrients triggering eutrophication of lakes (Schoefs et al., 2020, Masmoudi et al., 2013).

\subsection{Microalgae and biotechnology}

During the last centuries, the intensification of the utilization of fossil gas and oil reserves as a main source of energy for world development has generated more $\mathrm{CO}_{2}$ than the environment can absorb causing $\mathrm{CO}_{2}$ accumulation in the atmosphere at the origin of global warming (Moss et al., 2010). This, together with the eventual reduction of these reserves drove an intensive research for new energy sources. Because photosynthesis allows photosynthetic organisms to generate lipids, from atmospheric $\mathrm{CO}_{2}$, they constitute the best possibility to produce biofuels. The history of biofuels has been divided into four 'generations' (Gordon et al., 2019). The first and second generations were based on feedstock derived mainly from terrestrial plant waste streams whose production competes with food production. In contrast, the 3rd and 4th generations are based on microalgae, thereby reducing the food versus fuel concerns. From the combustion point of view, lipids utilization as biofuel generates $\mathrm{CO}_{2}$ and therefore they are not solving the $\mathrm{CO}_{2}$ emission in the atmosphere. From this point of view, biohydrogen looks more interesting because it is a zerocarbon fuel and produces water (Verhelst and Wallner, 2009, Kirubakaran et al., 2009). Therefore, hydrogen is considered as a clean, versatile, and promising alternative fuel with high energy density (142 MJ/kg) (Ainas et al., 2017). Because hydrogen is not readily available in nature, one of the main recent challenges is hydrogen production, including the production by microalgae (Ainas et al., 2017). Besides fuels, microalgae synthesize other metabolites of interest for food, 
health, cosmetic, energy or pharmaceutical industries (Mimouni et al., 2012, Heydarizadeh et al., 2013). Most of these compounds are high value molecules. For instance, the price of the natural carotenoid astaxanthin is over $\$ 14,000 \mathrm{US} \mathrm{kg}^{-1}$ (Scarsini et al., 2020). Microalgae can also be used in phytoremediation process or in preparation of element-enriched biomass for nutritional purposes (Babaei et al., 2017) or biofertilizers (Gojkovic et al., 2014).

From the biotechnological point of view, most of the processes comprises two steps. The first one aims at growing microalgae in favorable conditions in order to obtain biomass. The biomass is then placed in unfavorable growth conditions in order to induce the metabolic reorientation that ends by the accumulation of the desired compounds. Because the compounds accumulate inside the cells, they need to be extracted. Downstream processes are either destructive for the biomass that should be regrown after each extraction or nondestructive, offering the possibility of a milking process (Vinayak et al., 2015).

This contribution deals with the use of plasma in microalgal biotechnology. First, notions of plasma physics and chemistry are briefly presented and then plasma technology development in microalgal biotechnology is reviewed. The chapter ends with the applications of plasma in the field of water treatment and compound analyses.

\section{Plasma: the basic side}

Plasma physics usually describes one of the four fundamental states of matter consisting of neutral, positively and negatively charged atoms and molecules. The charged particles densities are equal and therefore the overall medium is electrically neutral. Non-thermal $\mathrm{Ar} / \mathrm{O}_{2}, \mathrm{~N}_{2} / \mathrm{O}_{2}$, He/air etc plasmas at working pressure comprised between atmospheric pressure and few Torr are applied in the biotechnology field since the associated species energy and temperature are suitable for soft 
organic matter. But these plasma phases remain an effective source of reactive nitrogen or oxygen species (RNS and ROS, respectively) towards biomolecules and living tissues. Therefore, such a gaseous state was recently applied to biology, medicine and agriculture fields despite its complex chemical pathway. Application of non-thermal plasmas has been therefore developed into several active research areas. Plasma medicine generates several chemical pathways, which can trigger cell functions (Okada et al., 2016, Graves, 2012). Furthermore, in agriculture, plasma has been applied recently for germination of seeds and growth of farm products (Kitazaki et al., 2012).

Radicals, ions, excited atoms and molecules, photons formed in the plasma phase are able to (de)activate micro-organisms and their reactivity was first applied to the sterilization and disinfection processes of inert liquid, solid materials (Straňák et al., 2006). The survival kinetic to exposition to plasma mixtures, typically comprised 2 or 3 decreasing phases characterized by different rates: the first phase, the fastest, corresponds to the stacked microorganisms killed by plasma-generated UV, the second phase, the slowest is due to physical erosion by the atomic oxygen bombardment. It is sometimes one with the lowest kinetics and sometimes combined with the third phase. Reactive neutral species generated from the plasma $\left(\mathrm{O}, \mathrm{O}_{3}, \mathrm{OH}, \mathrm{NO}, \mathrm{NO}_{2} \ldots\right)$, the so-called ROS and RNS are the major source of active species for the tissues engineering including sterilization, microorganisms adhesion and culture. ROS are double-sided with biological cells. In the one hand, they act as cellular signaling molecules triggering important physiological responses such as carotenogenesis in green microalgae (Lemoine and Schoefs, 2010) while in the other hand, ROS are able to oxidize any type of biological compounds, creating deleterious oxidative burst.

The plasma-treatment efficiency is mostly bound to the formed ROS and RNS, atoms and UV radiations. However, the other plasma species also interact with any (bio)organic material. Electrons driving the plasma physics impact the surface chemistry of polymers and therefore have 
a chemical effect on microorganisms on quite thick penetration ( $\mu \mathrm{m}$ scale: Rusanov et al. (1981)). Moreover, at the interface of plasma and aqueous microorganisms solution, the hydrated electrons convert the oxygen dissolved in water into superoxide $\mathrm{O}_{2}^{-}$, involved in various biological processes. Positive ions, predominant as charged plasma species, also interact and transfer their charge to solvated molecules until forming $\mathrm{H}_{3} \mathrm{O}^{+}$with water altering the lipid layer of cellular membrane. Plasma phase is initiated from an electrical discharge at variable frequencies and power which controls the ionic motion in the gaseous phase but which may also create electrostatic force by charge accumulation on the insulating materials as cells and then causes the cell membrane rupture (Laroussi et al., 2003). Furthermore, even if the heat effect is negligible with non-thermal plasma, some local and short-time but intensive heating may appear, especially with atmospheric plasma that alters the microorganism in contact.

\section{Plasma treatment and microalgal biotechnology}

\subsection{Preparation of dedicated nutrients for microalgal culture}

Because microalgae are often grown out of their natural environment, synthetic medium mimicking it more or less adequately are required. The ability of the artificial growth medium to support algal development depends on its composition and taxa may have particular requirements. For instance, the mixotrophic strains of Haematococcus pluvialis grow better on acetate than on carbon dioxide (Gateau et al., 2021). This is also the case of diatoms that usually cannot develop in the absence of silicium (Bachrach and Lefèvre, 1929, Martin-Jézéquel et al., 2000), an element required to build their highly decorated cell wall. Using inductively coupled plasma (ICP) synthesized nanosilica, Saxena et al. (2020) recorded a better biomass productivity and pigment content of three diatoms than with nonplasma synthesized Si. The authors attributed this result to 
the lower cell adhesion and aggregation that would impact positively the flow ability of nanosilica throughout the media because of its homogenous nature.

\subsection{Plasma modified surface for microalga immobilization}

Microalgal biotechnology requires cultivating a large volume of microalgal biomass. For this purpose, microalgae are grown either in open ponds or closed photobioreactor. Sometimes both systems are combined and recently new cultivation ways have been proposed. Because the cell density remains rather weak $\left(<0.5 \mathrm{~kg} \mathrm{~m}^{-3}\right)$, microalgal biotechnology usually faces a challenging downstream process that is microalgae harvesting. From the economic point of view, harvesting may represent as much as $20-30 \%$ of the production costs (Barros et al., 2015).

\subsubsection{Algal immobilization}

One way to reduce the harvesting cost consists in immobilizing microalgae which avoids regrowing microalga after each harvesting/extraction cycle used by traditional process. This has been developed since the 1980 s and is currently used by pharmaceutical, aquaculture, food and cosmetic industries, wastewater treatment and preconcentration of trace substances, energy production, including biohydrogen (for a review, see Barros et al. (2015)). Recently, we estimated the adhesion of Phaeodactylum tricornutum diatom on $\mathrm{N}_{2}, \mathrm{O}_{2}$, or $\mathrm{CO}_{2}$ plasma-modified polyethylene terephthalate (PET) surfaces by developing an original protocol using an atomic force microscopy (AFM) (Fig. 1). Measurements reported in this section were carried out using a commercial $\mathrm{Si}_{3} \mathrm{~N}_{4}$ probe (DNP10 probes, Bruker) whose cantilever has a nominal stiffness of 0.58

$\mathrm{N} \mathrm{m}^{-1}$. The principle of the method consisted in imaging microalga in AFM Contact Mode Imaging and using the probe for scratching the microalga under a definite constant applied force load to the 
contact. Depending on the plasma treatment, the number of scans required to completely remove the cell varies. If the cell/or a part of the cell was not totally removed from the substrate, a gradual increase of the applied force was adjusted until the cell was completely removed from the substrate. Finally, the adhesion force of the cell with the substrate was assessed by a specific parameter, which was defined by the product of the applied force with the number of scans needed to completely remove the cell from the substrate.
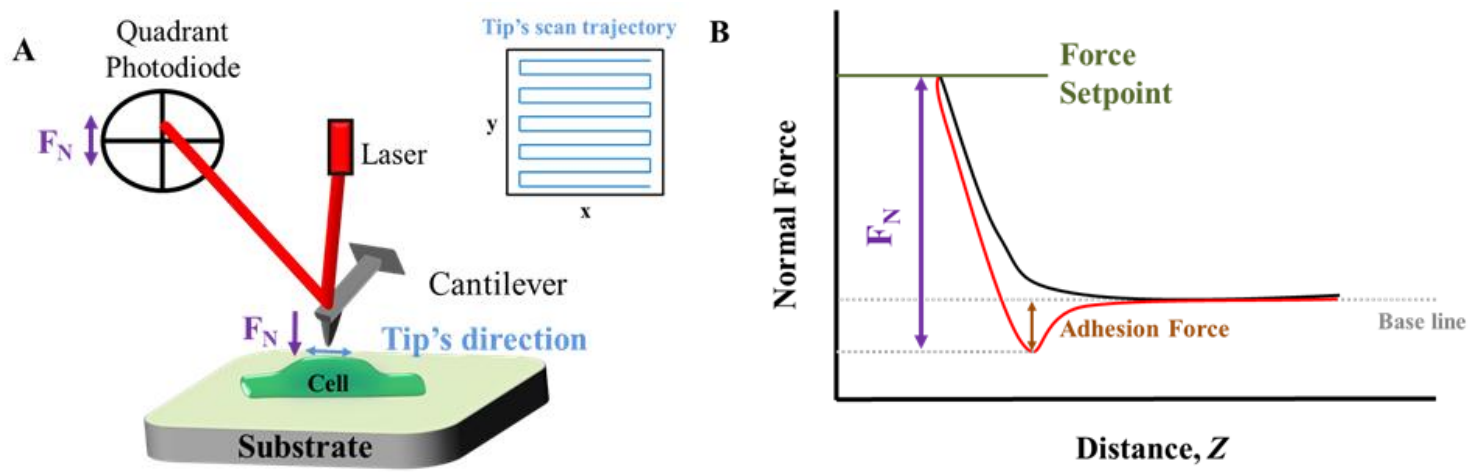

Fig. 1. Methodology for determining the adhesion force between the cell and the specific substrate. (A) Schematic illustration of the AFM imaging in contact mode. The AFM tip scans the sample surface $(\mathrm{x}, \mathrm{y})$ at a constant applied normal force by using a servo-loop system. (B) A typical force curve obtained on the cell in force spectroscopy mode in air. The applied normal force in imaging mode for the adhesion force measurement was determined by registering a force curve. The value of the applied force $\left(\mathrm{F}_{\mathrm{N}}\right)$ expressed in newton, is defined as the force difference in between the force setpoint (top) and minimum force of the curve corresponding to the adhesion force in between the AFM probe and the microalga (bottom). 

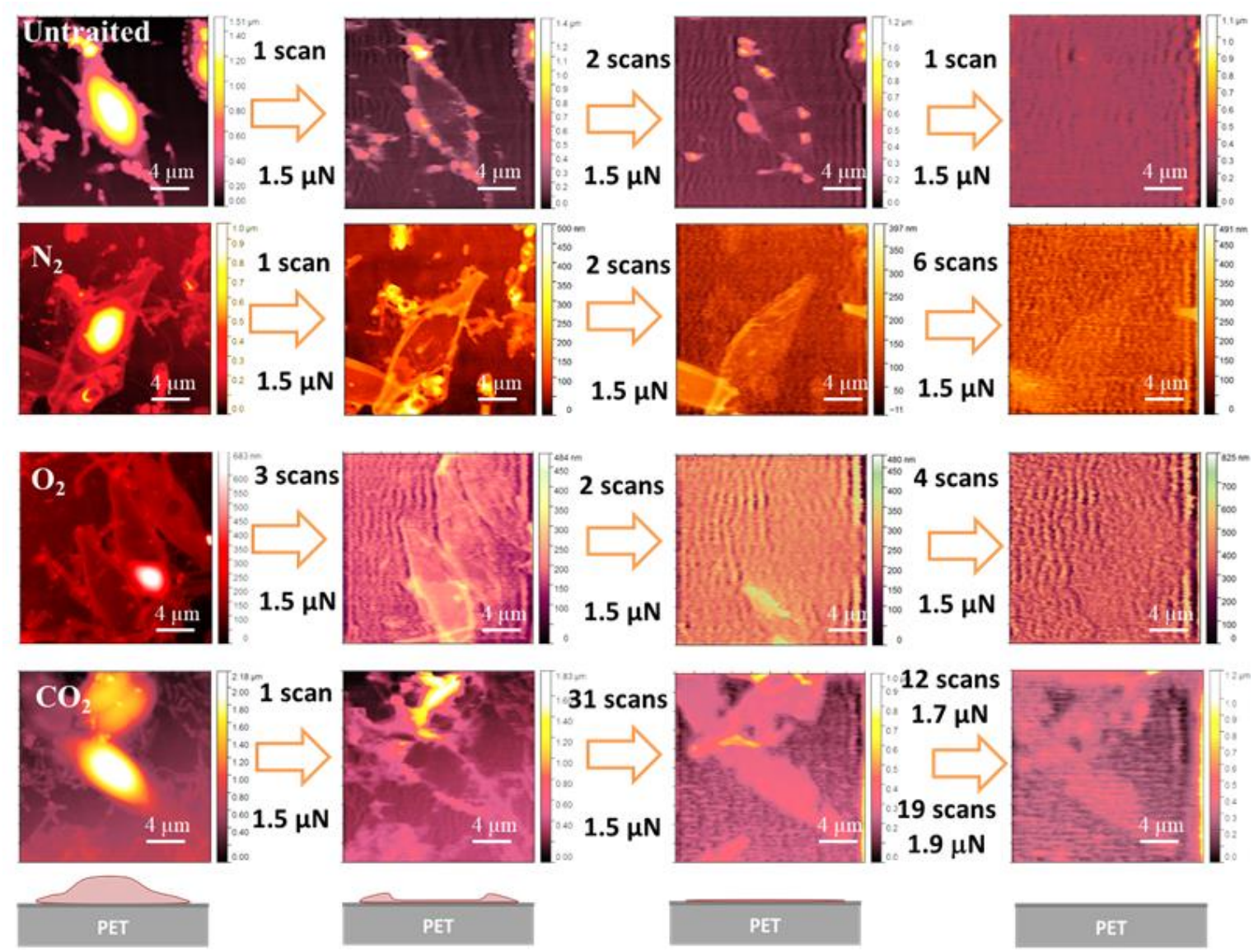

Fig. 2. AFM images of $P$. tricornutum cells immobilized on untreated and plasma-treated PET surfaces obtained in contact mode AFM in air during scratching. For completely removing the microalga from the substrate, it needs 4 scans at an applied normal force of $1.5 \mu \mathrm{N}$ for untreated PET substrate (A) 9 scans at an applied normal force of $1.5 \mu \mathrm{N}$ for $\mathrm{N}_{2}$ plasma-treated PET substrate, (B) 9 scans at an applied normal force of $1.5 \mu \mathrm{N}$ for $\mathrm{O}_{2}$ plasma-treated PET substrate, (C) 32 scans at an applied normal force of $1.5 \mu \mathrm{N}, 12$ scans at an applied normal force of $1.7 \mu \mathrm{N}$ and (D) 19 scans at an applied normal force of $1.9 \mu \mathrm{N}$ for $\mathrm{CO}_{2}$ plasma-treated PET substrate. 
Our results show that the diatom $P$. tricornutum had a better adherence to the plasma-treated PET substrates compared to the untreated PET substrate (Fig. 2). The microalga adherence was however different according to the plasma treatment (Fig. 3). $\mathrm{N}_{2}$ and $\mathrm{O}_{2}$ plasma-treated PET substrates improved only slightly the adherence whereas it was strongly increased on $\mathrm{CO}_{2}$ plasma-treated PET substrate (after 32 scans, the cell is still on the substrate) (Fig. 2). The differences in adherence can be explained by the different types and the diversity of functions created at the PET

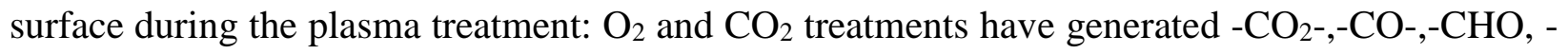
$\mathrm{OH}$ functions whereas $\mathrm{N}_{2}$ treatment allowed the creation of amine $\left(-\mathrm{NH}_{\mathrm{x}}\right)$ and amide $\left(\mathrm{CO}-\mathrm{N}_{\mathrm{x}^{-}}\right)$ functional groups, the two latter render the surface more hydrophilic (Tarrade et al., 2014). The extracellular matrix of diatoms being mostly composed by polar polymeric substances, they can strongly interact with the hydrophilic substrates via Van der Waals interactions and/or physical and/or chemical bonds. Consequently, P. tricornutum cells have a greater adherence with the plasma treated substrate generating hydrophilic chemical groups. By plotting the adhesion force parameter of the microalgae cell with different treated substrates, the trend of this parameter is similar to the trend of the surface energy (Fig. 3). 


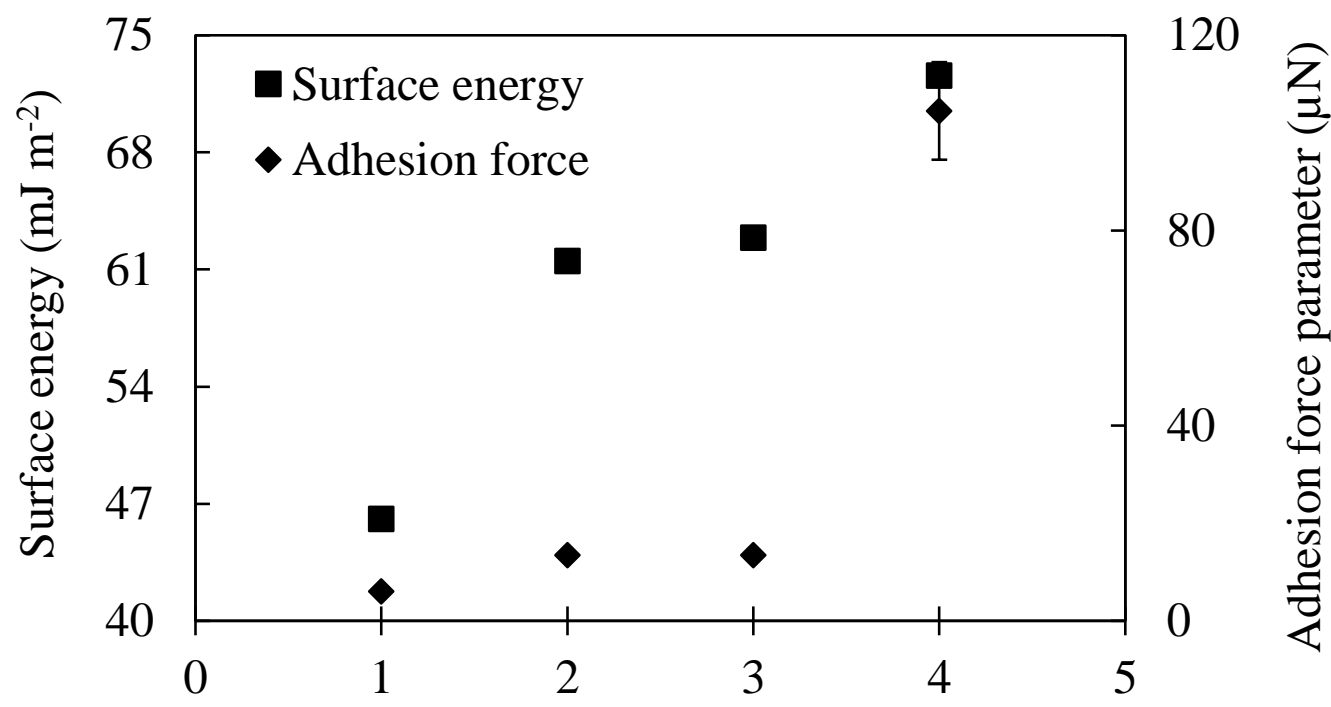

Plasma treatment

Fig. 3. Evolution of the surface energy (determined by measuring contact angles with water and dichloromethane and di-iodide methane and of the adhesion force of the P. tricornutum for different PET substrates

\subsection{Plasma treatment as a mean to improve algal productivity}

A explained previously, plasma treatment generates both chemical (ROS, RNS, UV and charged particles) and physical (shock waves and electric field) stresses able to modify or even deactivate i.e. kill microorganisms, including microalgae, notably through their mutagenesis capacity or/and the eventual dramatic pH decrease of the growth medium (Almarashi et al., 2020, Tang et al., 2008). The acidification of the growth medium during the plasma treatment may be responsible for the spectacular modification of microalga aspect at least for dinoflagellates (Tang et al., 2008). There are only a few studies dedicated to the impact of a plasma treatment on the physiology of algae. Microalgae respond to the oxidative stress generated by the plasma treatment by activating 
antioxidant defense mechanisms (SOD and catalase) and producing signaling molecules such as NOx (Almarashi et al., 2020). During long-term plasma treatment, these mechanisms may become inoperative, contributing to cell death (Table 1). Interestingly, and despite the fragility of chlorophyll (Chl) pigments (Schoefs, 2003, Schoefs, 2004), the cellular quota in Chl was not too much affected by a cold plasma treatment (120 s), allowing an effective photosynthesis in the cells having survived to the plasma treatment and thus biomass development. Longer treatments induced Chl bleaching and cell death (Schoefs, 2003). Microalgal movements as well as the metabolism ending with the accumulation of end products such as lipids might be affected because running defense mechanisms consume energy that is no longer available for running flagella motors and the activity of metabolic pathways (Tang et al., 2008). Accordingly, Almarashi et al. (2020) observed a decrease of the cellular lipid quota, lipid productivity and lipid quality in plasma-treated microalgae (more than $30 \mathrm{~s}$ ) with the formation of peroxided products and a modified fatty acid composition. The fatty acid being more saturated, their nutritional interest is reduced but could be used to produce biofuels. When compared to other microorganisms, microalgae appeared as rather resistant to the cumulative stresses induced by a plasma treatment, probably because they can rely on specific and efficient morphologic (rigid cell wall), enzymatic (ROS: Nguyen-Deroche et al. (2012)) and biophysical (Roháček et al., 2014) defense mechanisms, and also a wonderful plasticity of their metabolism (Heydarizadeh et al., 2019, Heydarizadeh et al., 2017).

The success of blue biotechnology resides partly on the obtention of very productive strains. For this purpose biodiversity can be used but the process is long and uncertain (Vinayak et al., 2015). To speed up the process of tailoring microalgae for specific applications (biodiesel, biohydrogen, etc.), the creation of mutants using targeted or untargeted approaches can be used 
(Zhang et al., 2016, Wang et al., 2016). Among the nontargeted approaches, atmospheric temperature plasma mutagenesis was developed recently for mutating microorganisms such as microalgae $(\mathrm{Xu}, 2014)$. Ar/O2 atmospheric pressure dielectric barrier discharge can cause mutations but the method presents numerous shortcomings, such as low mutation controllability, high operating voltage, inhomogeneous discharge, and low mutation efficiencies as demonstrated with the yeast Saccharomyces cerevisiae (Chen et al., 2010a). More recently, atmospheric pressure and room temperature plasma (ARTP) were introduced to induce mutations in microorganisms $(\mathrm{Li}$ et al., 2015). According to Cao et al. (2017), the particles produced by ARTP would activate the SOS repair mechanism with high fault tolerance level, producing a variety of mismatch sites in the repair process. Compared with the traditional untargeted mutation methods (chemical or physical such as the use of UV), ARTP presents several advantages: (1) it diversifies DNA damages, thus increasing the mutation rates and (2) ARTP is not toxic and no harmful matters are involved in the mutation process. The rate of mutation is dependent on the power source, gas flow, the distance between the emission source and carrier, and the processing time (Wang et al., 2010). The most flexible parameter of the plasma treatment is the processing time. The longer the treatment is the higher the mutation and death rates are (Chlorella: Cao et al. (2017), Crypthecodinium: Liu et al. (2015)). Because cell permeability changes according to cell development stage (Gateau et al., 2021), the death rate varies according to it as exemplified with the dinoflagellate Crypthecodinium cohii (Liu et al., 2015): it is higher when cells divide actively like during the exponential phase of growth. According to Wang et al. (2010), the mutation rate and the positive mutation rate were calculated using the following equations:

Mutation rate $(\mathrm{RM})(\%)=\mathrm{M} / \mathrm{T} \times 100$ (Equation 1)

and 
where $\mathrm{M}$ is the total colony-forming unit of the mutant strains with changed phenotype compared with the wild strain, and $\mathrm{P}$ is the $\mathrm{CFU}$ of the mutants with an improved phenotype.

As high as $96 \%$ of the hydrogen energy is generated from fossil fuels, tarnishing its lowcarbon image. It is known from a long time that microalgae such as Chlaymydomonas, Scenedesmus or Chlorella are able to produce hydrogen, the so-called biohydrogen (Khetkorn et al., 2017). Such a possibility looks great because the process involves the photosynthetic machinery that also consumes $\mathrm{CO}_{2}$, reinforcing the low-carbon potential of biohydrogen production. The protons and electrons needed by the biological process may be provided indirectly i.e. through the degradation of intracellular carbon storage compounds such as starch (direct biophotolysis) or directly i.e. from water splitting by water oxidase (direct biophotolysis) (Khetkorn et al., 2017). The former possibility will not be considered here because no paper reporting the involvement of plasma treatment was reported. The bottleneck of the latter process is the relatively low efficiency of the conversion of the energy associated with the absorbed photons into electrons and protons. One possibility for removing the bottleneck consists in reducing the cellular quota in Chl. This possibility has been successfully tested in land plants (Jenkins et al., 1989) and microalgae using targeted mutagenesis. Ban et al. (2019) used the nontargeted mutagenesis capacity of ARTP to select mutants of the green microalga Chlamydomonas reinhardtii with a reduced chlorophyll cellular quota to serve as biohydrogen producer. A mutant, named A4, presents a strongly reduced Chl content probably ensuring a better light transmittance in the culture and within the cells (Table 1) allowing an increase in hydrogen production. These results are in line with the mutants obtained using other methods (DNA- 
insertion: Kosourov et al. (2011), RNAi: (Oey et al., 2013), targeted mutagenesis: (Esquível et al., 2011). 
Table 1. Summary of the effects of ARTP on different microalgae.

\begin{tabular}{|c|c|c|c|c|c|c|c|c|c|c|c|c|}
\hline \multirow[t]{3}{*}{$\begin{array}{l}\text { Algal } \\
\text { category }\end{array}$} & Genus & Species & $\begin{array}{l}\text { Original } \\
\text { strain }\end{array}$ & $\begin{array}{l}\text { Mutant } \\
\text { strain }\end{array}$ & $\begin{array}{l}\text { Genetic stability } \\
\text { (generation) }\end{array}$ & \multicolumn{6}{|c|}{ Characteristics } & $\begin{array}{l}\text { Ref } \\
\text { ere }\end{array}$ \\
\hline & & & & & & Morphologic & Growth rate & \multicolumn{4}{|c|}{ Biochemistry } & \\
\hline & & & & & & & & $\begin{array}{l}\text { Chlo } \\
\text { roph } \\
\text { yll } \\
\text { (per } \\
\text { unit } \\
\text { cell } \\
\text { volu } \\
\text { me) }\end{array}$ & $\begin{array}{l}\text { Fatty } \\
\text { acid } \\
\text { meth } \\
\text { yl } \\
\text { ester }\end{array}$ & $\begin{array}{l}\text { Exop } \\
\text { olysa } \\
\text { cchar } \\
\text { ides }\end{array}$ & $\begin{array}{l}\text { Lip } \\
\text { id }\end{array}$ & \\
\hline
\end{tabular}




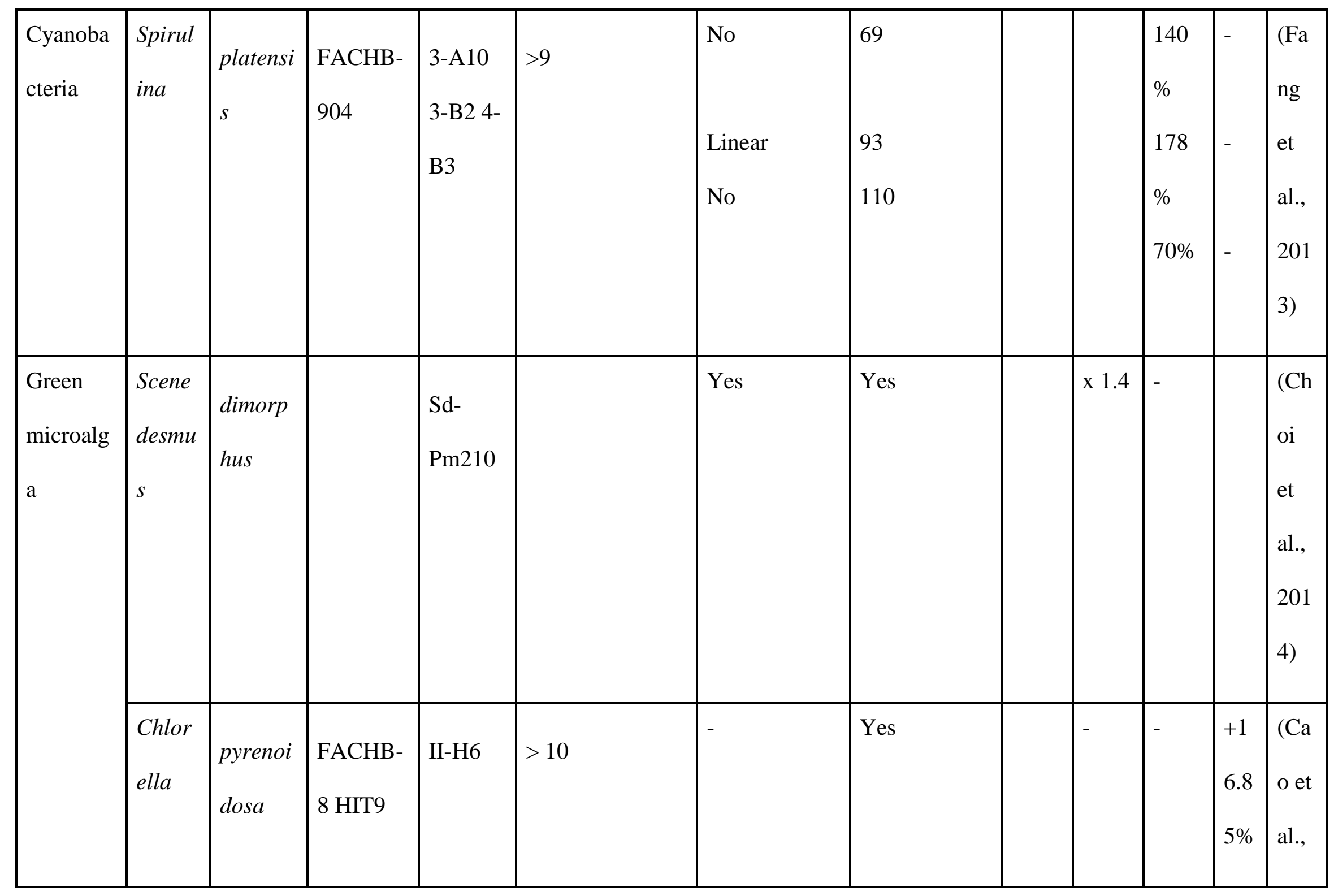




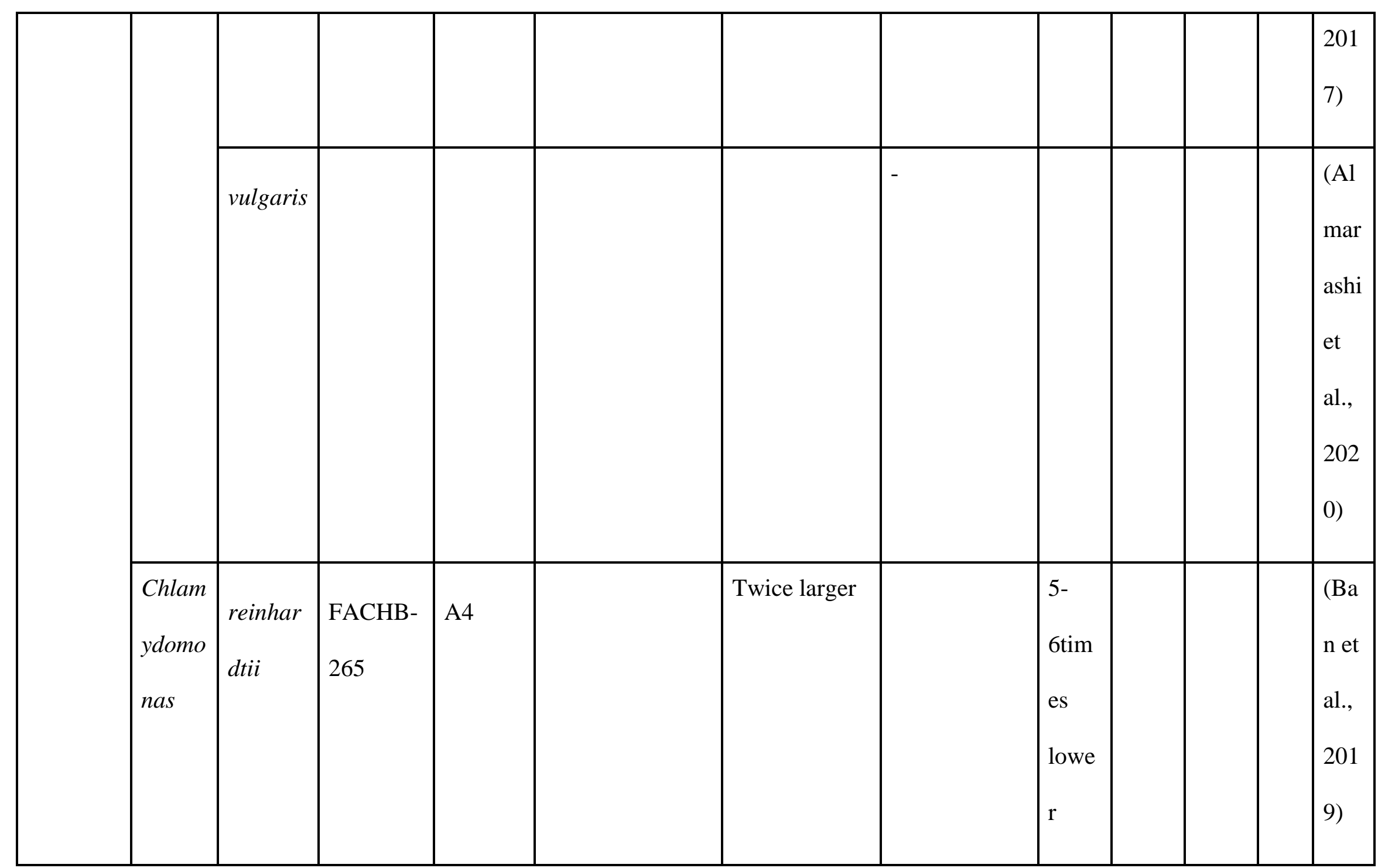




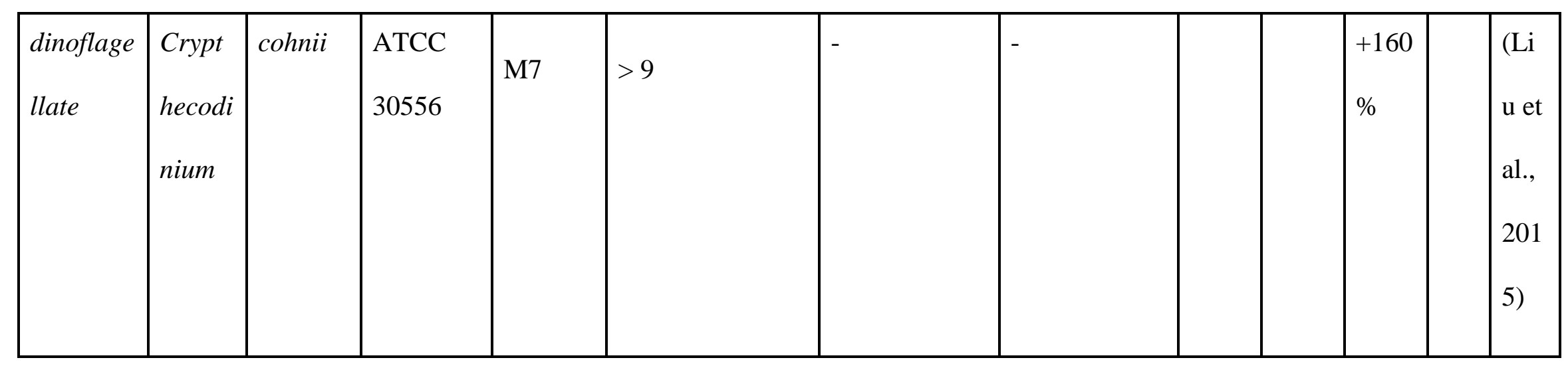




\subsection{Plasma and downstream processing}

Regardless of the biotechnological process used and the final products obtained from algae, they all start with growing algae to obtain biomass. The interest of plasma technologies has been described above. Once produced, the biomass is harvested and processed according to a dedicated downstream program generally involving dewatering, drying, grinding, extraction, and purification steps: drying, grinding and extraction are the most popular steps. A critical assessment of current microalga bioprocessing technology reveals that downstream processing also poses a number of important technical and economic challenges (Vinayak et al., 2015). There are several publications reporting the use of plasma technologies in different steps of the downstream process.

\subsubsection{Algal harvesting}

In most cases, the biomass contained in a photobioreactor or in an open pond is rather diluted. Consequently, the first step of a downstream process consists in microalga harvesting. Traditionally, biomass dewatering is achieved using continuous centrifugation of the culture, yielding an alga paste (Singh et al., 2013). Because, this step is time and energy consuming i.e. it is costly and not friendly from the environment point of view, alternative processes, including flocculation, have been developed (Pugazhendhi et al., 2019). Flocculation uses polymers as flocculants to harvest the cultivated microalgae. Chitosan, a naturally large molecule with many functional groups such as free amino groups and hydroxyl groups, has been considered as a possible flocculant (Lu et al., 2011). Actually, cationic active groups in chitosan chains can neutralize negatively charged algal cells resulting in adsorption (Thakur and Thakur, 2014). Unfortunately, chitosan is poorly soluble under neutral conditions (Jia et al., 2016) and grafted 
copolymers are used to improve water solubility and effectiveness of flocculation (Wang et al., 2007). Copolymer rafting is usually initiated by chemical and radiation methods (Wang et al., 2008). Recently, plasma-initiated polymerization was introduced to prepare chitosan-based flocculants (Yu et al., 2014). Using this method, Sun et al. (2017) prepared an acrylamide and dimethyl diallyl ammonium chloride-grafted chitosan [CSg-P(AM-DMDAAC)] that was tested for its capacity to remove low density microalgae. The flocculation performance of CS-gP(AMDMDAAC) was found to be higher than those of other flocculants such as cationic polyacrylamide and polymeric aluminum and iron. Optimal flocculation (better than the commercially available) was obtained with a polymer composed of $20 \%$ monomer concentration and 7:3 polyacrylamide:chitosan ratio $\left(40 \mathrm{~W}\right.$ discharge power, $90 \mathrm{~s}$ discharge time, $50^{\circ} \mathrm{C}$ postpolymerization temperature, and $24 \mathrm{~h}$ post-polymerization time) (Sun et al., 2019).

\subsubsection{Dry matter treatment}

The next steps in biomass processing consist in drying and extracting compounds from the biomass. As mentioned above, biohydrogen can be produced along different processes. Beside the nondestructive possibilities described in section 3.3, biohydrogen can also be obtained through

microalgal biomass destruction. The latter possibility may involve microwave-induced pyrolysis i.e. a thermal decomposition of organic components in an oxygen free atmosphere to produce biooil, gas mixture (syngas) and charcoal (coal made by burning photosynthetic organisms) (Brennan and Owende, 2010). During pyrolysis, microwave heating may stimulate the breaking of compounds into gaseous molecules such as $\mathrm{H}_{2}$. Many studies have been carried out in recent years to characterize the pyrolysis behavior of microalgae biomass (Lin et al., 2014). Using an atmospheric-pressure microwave plasma (APS), Lin et al. (2014) succeeded to pyrolyze the 
unicellular cyanobacterium Spirulina sp.. Interestingly, the duration of the plasma treatment required for complete conversion of algae to $\mathrm{H}_{2}$ is almost independent of the reaction temperature. In contrast, the microwave power used in the reaction was found to be proportional to the rate of $\mathrm{H}_{2}$ production. The optimal $\mathrm{H}_{2}$ production rate was obtained with $1000 \mathrm{~W}$ discharge power. In this condition, $60 \mathrm{mg}$ of $\mathrm{H}_{2}$ was produced from $1 \mathrm{~g} \mathrm{DW}$ of Spirulina sp. (Lin et al., 2014).

\section{Water and wastewater treatment}

Global warming, anthropic activities, water pollution and eutrophication of water bodies have increased the occurrence of algal and cyanobacterial blooms, degrading the quality of freshwater sources worldwide (Paerl and Paul, 2012, Zamyadi et al., 2012). Beside blocking filter beds in water supply treatment processes, deteriorating plug or corroding pipelines and increasing the amount of chlorination by-products, algal and cyanobacterial blooms are frequently associated with the accumulation in the water bodies (including drinking water reservoirs) of dangerous toxins and taste-and-odor-compounds (Lawton et al., 2003). Therefore, before further use, these types of water need to be treated. A first possibility consists in harvesting microalgae, a difficult task with low-algal load waters. Among the different possibilities coagulation-flocculation is the safest, most effective, and widely used because this treatment does not destroy algal cells, avoiding the eventual release of toxins in the medium (Rashid et al., 2013). Removing microalgae from water may however not be sufficient because during the process, toxins and taste-and-odorcompounds, including geosmin and 2-methylisoborneol that are semi-volatile metabolites, might be released. Consequently, to avoid any risk, these compounds need to be destroyed. Beside physical methods such as activated carbon adsorption and filtration (Rashid et al., 2013) and biological methods such as adsorption by tolerant organisms that are often affected by environmental factors (Chen et al., 2010b), chemical methods involving advanced oxidation 
processes (photocatalysis, UV photolysis, ultrasonication, and ozone-based processes) appear as alternative methods. Dielectric barrier discharge (or DBD plasma) has been used to produce long lifetime ozone in air and short lifetime ROS in water or water vapor (Lebout, 1959). The capacity of ROS to oxidize any type of biological compounds, can be exploited for developing a process aiming at inactivating microalgae that would pollute water bodies and/or water reservoirs (Mizukoshi et al., 2018). For instance, Kim et al. (2019) calculated a 89\% efficiency in eliminating microalgae after a $24 \mathrm{~h}$ treatment of plasma. Using a similar method, Nisol et al. (2019) eliminated the toxic filamentous cyanobacterium Dolichospermum sp. after a 6 min treatment (Table 2). A better understanding of the ROS action mechanism(s) on microalgae would greatly help in optimizing the process. Electronic microscope pictures showed surface modification i.e. shrinkage before disruption (Kim et al., 2019) (Fig. 4).

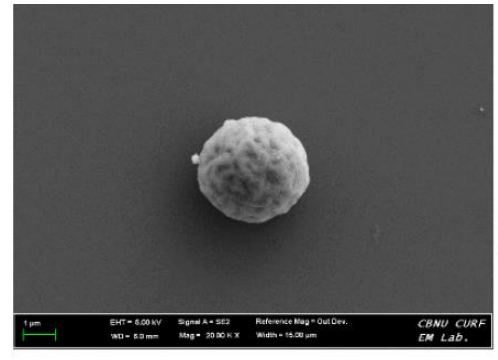

Cyanobacteria (Original)

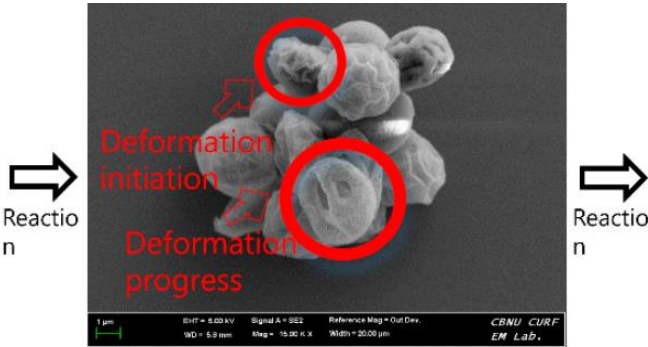

Changes in cell surface

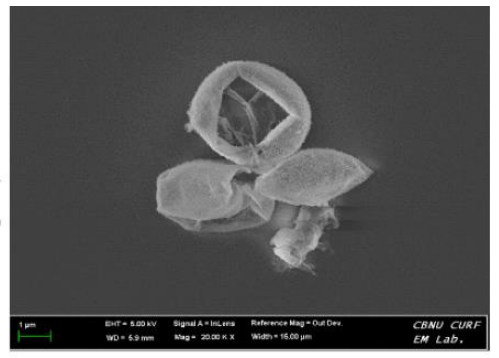

Destruction of cell surface

Fig. 4. Scanning electron microscopy image showing the morphological modifications induced by the plasma treatment of blooming cyanobacteria. Reprinted from Kim et al. (2019).

Table 2. Summary of the effectiveness of plasma treatment for the eradication of microalgae from wastewater.

\begin{tabular}{|l|l|l|l|l|l|l|}
\hline & Plasma & Time of & Efficiency & Remaining & References \\
& & type & exposure & $(\%)$ & nonviable & \\
\hline
\end{tabular}




\begin{tabular}{|c|c|c|c|c|c|c|}
\hline & & & & & $(\%)$ & \\
\hline Groups & Taxa & & & & & \\
\hline $\begin{array}{l}\text { Cyanobact } \\
\text { eria }\end{array}$ & - & $\begin{array}{l}\text { cold } \\
\text { plasma }\end{array}$ & $24 \mathrm{~h}$ & 88.8-94 & & $\begin{array}{l}\text { (Kim et al., } \\
2019 \text { ) }\end{array}$ \\
\hline $\begin{array}{l}\text { Cyanobact } \\
\text { eria }\end{array}$ & $\begin{array}{l}\text { Dolichospe } \\
\text { rmum sp. }\end{array}$ & $\begin{array}{l}\text { cold } \\
\text { plasma }\end{array}$ & $6 \mathrm{~min}$ & 87.0 & 80 & $\begin{array}{l}\text { (Nisol et } \\
\text { al., 2019) }\end{array}$ \\
\hline Green alga & $\begin{array}{l}\text { Scenedesm } \\
\text { us } \mathrm{sp} .\end{array}$ & $\begin{array}{l}\text { cold } \\
\text { plasma }\end{array}$ & $6 \mathrm{~min}$ & $<87.0$ & - & $\begin{array}{l}\text { (Nisol et } \\
\text { al., 2019) }\end{array}$ \\
\hline
\end{tabular}

Zhang et al. (2012) degraded the cyanobacterial toxin microcystin-LR, using glow discharge plasma generated above the water surface. In this process, reactions occur only at the gas solution interface, resulting in a limitation on the rate of degradation. In the same manner, Jo et al. (2014) applied atmospheric-pressure underwater plasma system for decomposing two odorous organic compounds, geosmin and 2-methyl isoborneol, from cyanobacteria. Chlorinated volatile organic compounds (CleVOCs) such as chloromethane, chloroethane, chloroethylene and aromatic chlorides belong to an another family of compounds produced directly or indirectly by microalgae (Achyuthan et al., 2017). Beside their unpleasant smell, these compounds are harmful for the environment and health (Li et al., 2020b, Tsai, 2017). Chemical, physical and biological methods have been proposed for air treatment (Li et al., 2020a, Li et al., 2020b, Tsai, 2017). Biological processes involve several steps such as absorption, diffusion and biodegradation. The efficiency of the process requires the involvement of resistant microorganisms as well as a good mass transfer 
between the different steps, a transfer that can be difficult when less-water-soluble CleVOCs are considered (Ye et al., 2019). Non-thermal plasma (NTP), eventually coupled to another method, has been proposed as a pretreatment step to facilitate the mass transfer because it could convert less-water-soluble CleVOCs to more soluble intermediates (Schiavon et al., 2017). Coupling DBD with biotrickling filters allowed Jiang et al. (2018) to reduce significantly the number of byproducts and to improve both the water solubility and biodegradability of the intermediates of waste air containing 1,2-dichloroethane. Because NTP can be lethal (see above), the treatment was also limiting the biodiversity and abundance of the microbial community involved in the process. Metals and especially heavy metals are another kind of water pollutants needed to be removed because they are toxic for living organisms (Masmoudi et al., 2013). Dead microalgal biomass has been considered as a mean for water decontamination of polluting metals (Lin et al., 2020). Mahan et al. (1989) tested the capacity of three taxa belonging to green algae (i.e. Stichococcus bacillaris, Chlamydomonas reinhardtti, Chlorella pyrenoidosa) for their capacity to quench heavy metals. The determination of metal-bound to the dead biomass using ICP coupled to different ionization processes revealed the high binding capacity of microalgae for $\mathrm{Pb}, \mathrm{Fe}, \mathrm{Cu}$, Ni, Zn, Cd, Sr (Mahan et al., 1989) , Hg (Mitchell et al., 1986) and Au (Greene et al., 1986).

\section{Plasma and intracellualr metal analysis}

It is well established that an unbalance in metal elements may cause severe troubles to cells, including microalgae (Masmoudi et al., 2013, Bertrand et al., 2001). It is thus crucial in many studies to quantify the cellular composition in metals, heavy metals and other nonmetal elements. The determination of the intracellular metal quota usually involves sample digestion (Roháček et al., 2014) for further analyses using total reflection X-ray fluorescence (TXRF), particle-induced 
X-ray fluorescence (PIXE) (Bertrand et al., 2003), electrothermal atomic absorption spectrometry (ETAAS), inductively coupled plasma-atomic emission spectrometry (ICP-AES) and/or inductively coupled plasma-mass spectrometry (ICP-MS) (Cerchiaro et al., 2013). Commonly, ICP-MS is hyphenated with a tool that is used to separate the compounds of interest from the other compounds before MS analysis. For instance, Bednarik et al. (2018) used thin-layer chromatography as an alternative to HPLC to determine the selenoamino acids by diode laser thermal vaporization ICP MS (DLTV ICP MS) whereas Li et al. (2016) used capillary electrophoresis coupled IPC (CE-IPC MS) to determine $\mathrm{Pb}$ (II) ions, trimethyl lead and triethyl lead in seaweeds. These tools are however inadequate for individual cell study. This limitation has recently been overcome through the emergence of single cell-inductively coupled plasma-mass spectrometry (SC-ICP-MS). SC-ICP-MS technology consists in the introduction of cells into the ICP-MS system using a modified nebulizer working in conjunction with a peristaltic pump delivering small volumes of a cell suspension into the spray chamber. Optimizing cell concentration and flow rate, allows individual cells to enter the plasma. Cells become ionized in the plasma as discrete plumes that are subsequently detected as pulsed signals by the mass spectrometer. Three types of information are derived from the signal: (1) the elemental mass of compounds in an individual (proportional to the pulsed signal), (2) the cell concentration within the cell suspension (related to the pulse signal frequency) and (3) the extracellular concentration of an analyte within the cell suspension (the baseline signal in the absence of a pulse) (Shen et al., 2019). Using SC-ICP-MS, Shen et al. (2019) monitored the cell status and quantified copper uptake and accumulation by the toxic cyanobacteria Microcystis aeruginosa following exposure to copper-based algaecides. The optimized protocol allows the detection of cell suspensions directly after suitable dilution avoiding cell preparation steps such as washings and re-suspensions, 
allowing fast time-course measurement (1-4 h depending on the concentration) after the herbicide application (Shen et al., 2019). Developments of SC-ICP-MS will probably make this technique a major tool for microalgal components analysis. Table 3 summarizes the type of components addressed by this method in microalga. 


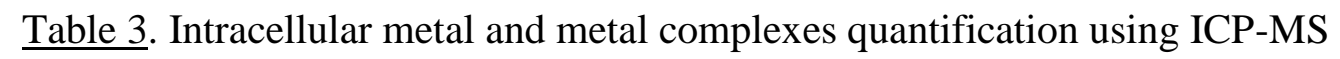

\begin{tabular}{|c|c|c|c|c|c|c|c|c|}
\hline & & \multicolumn{7}{|l|}{ Heavy metals } \\
\hline & & $\mathrm{Cu}$ & $\mathrm{Mg}$ & Cell concentration & $\begin{array}{l}\text { Selenomethio } \\
\text { nine }\end{array}$ & Selenocysteine & As (III) & As (V) \\
\hline Extracellular & & $\begin{array}{l}1 \mu \mathrm{g} \mathrm{L}^{-1} \\
\text { (Shen et al., } \\
2019)\end{array}$ & $\begin{array}{l}0.2 \mu \mathrm{g} \mathrm{L}^{-1} \\
\text { (Shen et al., } \\
2019)\end{array}$ & & & & & \\
\hline Cyanobacteria & $\begin{array}{l}\text { Microcystis } \\
\text { aeruginosa }\end{array}$ & $\begin{array}{l}65 \text { ag cell }^{-1} \\
\text { (Shen et al., } \\
2019)\end{array}$ & $98 \mathrm{ag} \mathrm{cell}^{-1}$ & $\begin{array}{l}3000 \mathrm{~mL}^{-1} \\
\text { (Shen et al., 2019) }\end{array}$ & & & & \\
\hline Chlorophyta & $\begin{array}{l}\text { Chlorella } \\
\text { vulgaris, } \\
\text { strain R117 }\end{array}$ & - & - & - & $\begin{array}{l}161-197 \mu \mathrm{g} \mathrm{g}^{-} \\
1 \text { (Bednarik et } \\
\text { al., 2018) }\end{array}$ & $\begin{array}{l}\text { 196-247 } \mu \mathrm{g} \mathrm{g}^{-1} \\
\text { (Bednarik et } \\
\text { al., 2018) }\end{array}$ & & \\
\hline
\end{tabular}




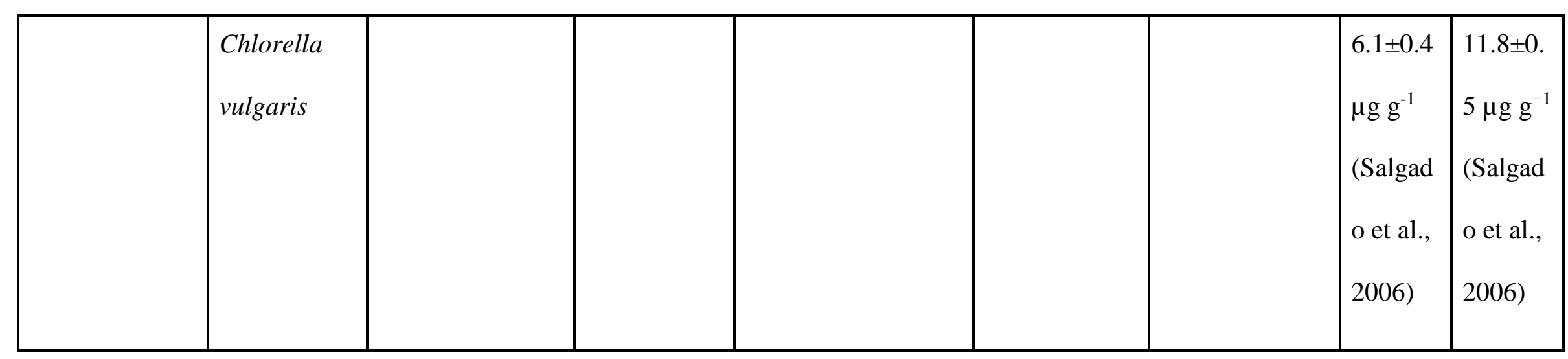


Conclusions and perspectives

In this chapter, we summarized how plasma technology can be combined with different fields dealing with microalgae. Clearly, plasma technology is a very promising tool for the optimization of microalga technology and biotechnology. The introduction of plasma in biology is rather recent. A literature search revealed a first publication early in the 21st Century (Fig. 5). Since, the field is developing slowly but regularly (Fig. 5A) and arouses interest as the yearly citation number increases. Let's bet it will continue, making the combination of plasma technology and microalgae a major interface between biology, chemistry and physics.

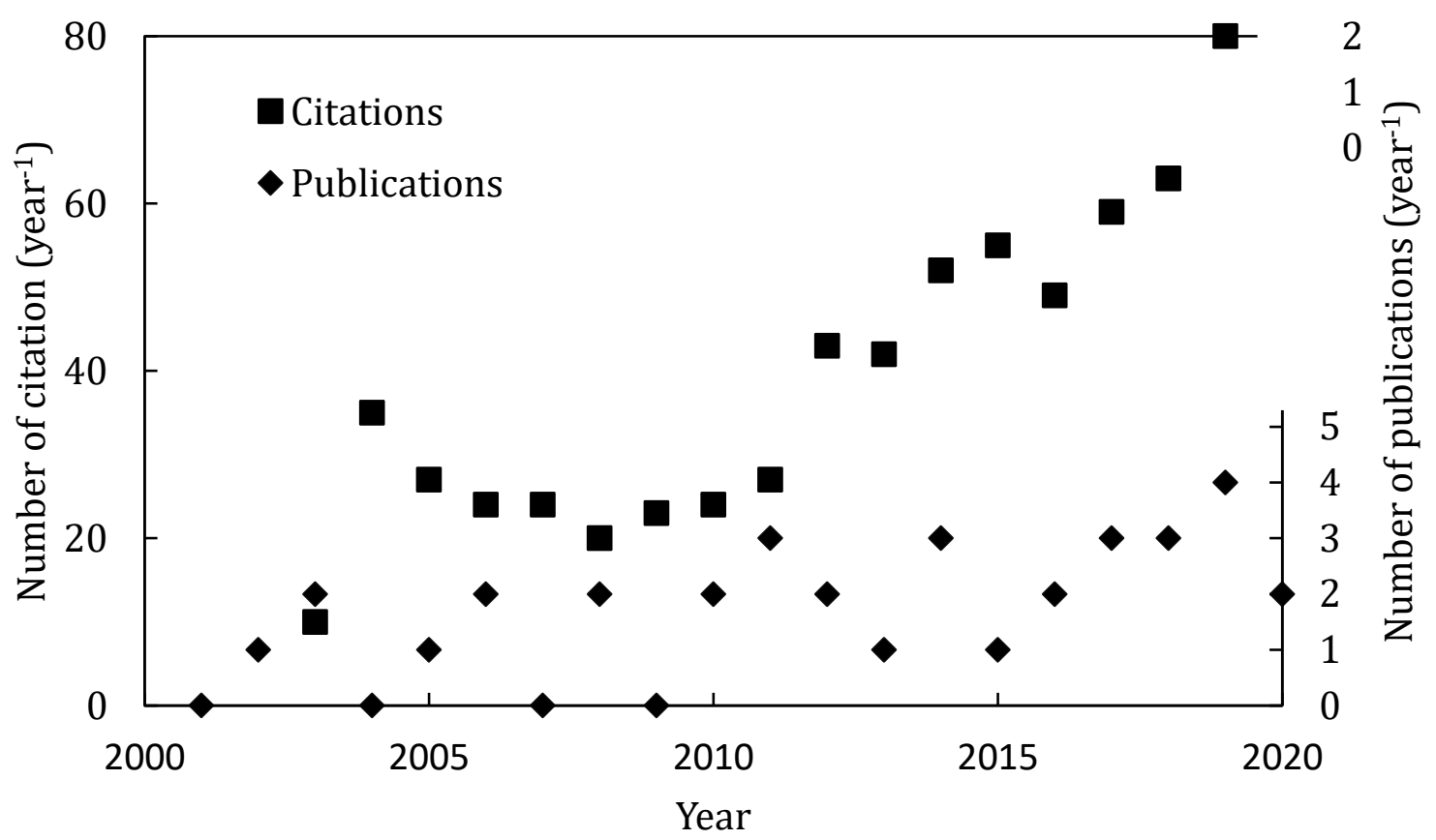

Fig 5. Bibliometry data concerning the field 'plasma and microalgae'.

The data obtained after interrogating Web of Science with the question 'TITLE: (plasma* not (membrane* or plasmalemma*)) AND TITLE: (alga or algae or algal)' (September 2020).

Bibliography 
ACHYUTHAN, K. E., HARPER, J. C., MANGINELL, R. P. \& MOORMAN, M. W. 2017. Volatile metabolites emission by in vivo microalgae-an overlooked opportunity? Metabolites, 7, 39.

AINAS, M., HASNAOUI, S., BOUARAB, R., ABDI, N., DROUICHE, N. \& MAMERI, N. 2017. Hydrogen production with the cyanobacterium Spirulina platensis. International Journal of Hydrogen Energy, 42, 4902-4907.

ALMARASHI, J. Q. M., EL-ZOHARY, S. E., ELLABBAN, M. A. \& ABOMOHRA, A. E.-F. 2020. Enhancement of lipid production and energy recovery from the green microalga Chlorella vulgaris by inoculum pretreatment with low-dose cold atmospheric pressure plasma (CAPP). Energy Conversion and Management, 204, 112314.

BABAEI, A., RANGLOVÁ, K., MALAPASCUA, J. R. \& MASOJÍDEK, J. 2017. The synergistic effect of selenium (selenite, $-\mathrm{SeO}_{3}{ }^{2-}$ ) dose and irradiance intensity in Chlorella cultures. AMB Express, 7, article \#56.

BACHRACH, E. \& LEFĖVRE, M. 1929. Contribution à l'étude du rôle de la silice chez les êtres vivants. Observation sur la biologie des diatomées. Journal de Physiologie et de Pathologie Générale, 27, 241-249.

BAN, S., LIN, W., LUO, Z. \& LUO, J. 2019. Improving hydrogen production of Chlamydomonas reinhardtii by reducing chlorophyll content via atmospheric and room temperature plasma. Bioresource Technology, 275, 425-429.

BARROS, A. I., GONÇALVES, A. L., SIMÕES, M. \& PIRES, J. C. M. 2015. Harvesting techniques applied to microalgae: A review. Renewable and Sustainable Energy Reviews, 41, 1489-1500.

BEDNARIK, A., KUTA, J., VU, D. L., RANGLOVA, K., HROUZEK, P., KANICKY, V. \& PREISLER, J. 2018. Thin-layer chromatography combined with diode laser thermal vaporization inductively coupled plasma mass spectrometry for the determination of selenomethionine and selenocysteine in algae and yeast. Journal of Chromatography $A$, 1533, $199-207$.

BERTRAND, M., SCHOEFS, B., SIFFEL, P., ROHACEK, K. \& MOLNAR, I. 2001. Cadmium inhibits epoxidation of diatoxanthin to diadonixanthin in the xanthophyll cycle of the marine diatom Phaeodactylum tricornutum. FEBS Letters, 508, 153-156.

BERTRAND, M., WEBER, G. \& SCHOEFS, B. 2003. Metal determination and quantification in biological material using particle-induced X-ray emission. TrAC Trends in Analytical Chemistry, 22, 254-262.

BRENNAN, L. \& OWENDE, P. 2010. Biofuels from microalgae-A review of technologies for production, processing, and extractions of biofuels and co-products. Renewable and Sustainable Energy Reviews, 14, 557-577.

CAO, S., ZHOU, X., JIN, W., WANG, F., TU, R., HAN, S., CHEN, H., CHEN, C., XIE, G. J. \& MA, F. 2017. Improving of lipid productivity of the oleaginous microalgae Chlorella pyrenoidosa via atmospheric and room temperature plasma (ARTP). Bioresource Technology, 244, 1400-1406.

CERCHIARO, G., MANIERI, T. M. \& BERTUCHI, F. R. 2013. Analytical methods for copper, zinc and iron quantification in mammalian cells. Metallomics, 5, 1336-45.

CHEN, H., BAI, F. \& XIU, Z. 2010a. Oxidative stress induced in Saccharomyces cerevisiae exposed to dielectric barrier discharge plasma in air at atmospheric pressure. IEEE Transactions on Plasma Science, 38, 1885-1891.

CHEN, X., YANG, X., YANG, L., XIAO, B., WU, X., WANG, J. \& WAN, H. 2010b. An effective pathway for the removal of microcystin LR via anoxic biodegradation in lake sediments. Water Research, 44, 1884-1892.

CHOI, J. I., YOON, M., JOE, M., PARK, H., LEE, S. G., HAN, S. J. \& LEE, P. C. 2014. Development of microalga Scenedesmus dimorphus mutant with higher lipid content by radiation breeding. Bioprocess and Biosystems Engineering, 37, 2437-2444. 
COALE, K. H., JOHNSON, K. S., FITZWATER, S. E., GORDON, R. M., TANNER, S., CHAVEZ, F. P., FERIOLI, L., SAKAMOTO, C., ROGERS, P., MILLERO, F., STEINBERG, P., NIGHTINGALE, P., COOPER, D., COCHLAN, W. P., LANDRY, M. R., CONSTANTINOU, J., ROLLWAGEN, G., TRASVINA, A. \& KUDELA, R. 1996. A massive phytoplankton bloom induced by an ecosystem-scale iron fertilization experiment in the equatorial Pacific Ocean. Nature, 383, 495-501.

ESQuíVEL, M. G., AMARO, H. M., PINTO, T. S., FEVEREIRO, P. S. \& MALCATA, F. X. 2011. Efficient $\mathrm{H}_{2}$ production via Chlamydomonas reinhardtii. Trends in Biotechnology, 29, 595-600.

FANG, M., JIN, L., ZHANG, C., TAN, Y., JIANG, P., GE, N., HEPING, L. \& XING, X. 2013. Rapid mutation of Spirulina platensis by a new mutagenesis system of atmospheric and room temperature plasmas (ARTP) and generation of a mutant library with diverse phenotypes. PLoS One, 8, e77046.

GATEAU, H., BLANCKAERT, V., VEIDL, B., BURLET-SCHILTZ, O., PICHEREAUX, C., GARGAROS, A., MARCHAND, J. \& SCHOEFS, B. 2021. Application of pulsed electric fields for the biocompatible extraction of proteins from the microalga Haematococcus pluvialis. Bioelectrochemistry, 137, 107588.

GOJKOVIC, Ž., VÍLCHEZ, C., TORRONTERAS, R., VIGARA, J., GÓMEZ-JACINTO, V., JANZER, N., GÓMEZ-ARIZA, J.-L., MÁROVÁ, I. \& GARBAYO, I. 2014. Effect of selenate on viability and selenomethionine accumulation of Chlorella sorokiniana grown in batch culture. TheScientificWorldJournal, 2014, article \#401265.

GORDON, D., MERZ, C. R., GURKE, S. \& SCHOEFS, B. 2019. Bubble farming: scalable microcosms for diatom biofuel and the next green revolution. In: SECKBACH, J. \& GORDON, R. (eds.) Diatoms: Fundamentals \& Applications. Beverly, MA, USA.: WileyScrivener.

GRAVES, D. B. 2012. The emerging role of reactive oxygen and nitrogen species in redox biology and some implications for plasma applications to medicine and biology. Journal of Physics D: Applied Physics, 45, 263001.

GREENE, B., MITCHELL, P. G. \& SNEDDON, J. 1986. Direct determination of gold in solid algal cells by direct-current argon plasma emission-spectrometry with introduction by electrothermal atomization. Spectroscopy Letters, 19, 101-111.

HEYDARIZADEH, P., BOUREBA, W., ZAHEDI, M., HUANG, B., MOREAU, B., LUKOMSKA, E., COUZINET-MOSSION, A., WIELGOSZ-COLLIN, G., MARTIN-JEZEQUEL, V., BOUGARAN, G., MARCHAND, J. \& SCHOEFS, B. 2017. Response of $\mathrm{CO}_{2}$-starved diatom Phaeodactylum tricornutum to light intensity transition. Philosophical Transactions of the Royal Society B: Biological Sciences, 372, 20160396.

HEYDARIZADEH, P., POIRIER, I., LOIZEAU, D., ULMANN, L., MIMOUNI, V., SCHOEFS, B. \& BERTRAND, M. 2013. Plastids of marine phytoplankton produce bioactive pigments and lipids. Marine Drugs, 11, 3425-3471.

HEYDARIZADEH, P., VEIDL, B., HUANG, B., LUKOMSKA, E., WIELGOSZ-COLLIN, G., COUZINET-MOSSION, A., BOUGARAN, G., MARCHAND, J. \& SCHOEFS, B. 2019. Carbon orientation in the diatom Phaeodactylum tricornutum: the effects of carbon limitation and photon flux density. Frontiers in Plant Science, 10, 471.

HOPES, A. \& MOCK, T. 2015. Evolution of microalgae and their adaptations in different marine ecosystems. eLS, 1-9.

JENKINS, C. L., EDWARDS, G. E. \& ANDREWS, J. 1989. Reduction in chlorophyll content without a corresponding reduction in photosynthesis and carbon assimilation enzymes in yellow-green oil yellow mutants of maize. Photosynth Res, 20, 191-205.

JIA, S., YANG, Z., REN, K., TIAN, Z., DONG, C., MA, R., YU, G. \& YANG, W. 2016. Removal of antibiotics from water in the coexistence of suspended particles and natural organic 
matters using amino-acid-modified-chitosan flocculants: A combined experimental and theoretical study. Journal of Hazardous Materials, 317, 593-601.

JIANG, L., LI, S., CHENG, Z., CHEN, J. \& NIE, G. 2018. Treatment of 1,2-dichloroethane and nhexane in a combined system of non-thermal plasma catalysis reactor coupled with a biotrickling filter. Journal of Chemical Technology \& Biotechnology, 93, 127-137.

JO, J. O., KIM, S. D., LEE, H. J. \& MOK, Y. S. 2014. Decomposition of taste-and-odor compounds produced by cyanobacteria algae using atmospheric pressure plasma created inside a porous hydrophobic ceramic tube. Chemical Engineering Journal, 247, 291-301.

KHETKORN, W., RASTOGI, R. P., INCHAROENSAKDI, A., LINDBLAD, P., MADAMWAR, D., PANDEY, A. \& LARROCHE, C. 2017. Microalgal hydrogen production - A review. Bioresource Technology, 243, 1194-1206.

KIM, H. J., NAM, G. S., JANG, J. S., WON, C. H. \& KIM, H. W. 2019. Cold Plasma Treatment for Efficient Control over Algal Bloom Products in Surface Water. Water, 11.

KIRUBAKARAN, A., JAIN, S. \& NEMA, R. K. 2009. A review on fuel cell technologies and power electronic interface. Renewable and Sustainable Energy Reviews, 13, 2430-2440.

KITAZAKI, S., KOGA, K., SHIRATANI, M. \& HAYASHI, N. 2012. Growth enhancement of radish sprouts induced by low pressure $\mathrm{O}_{2}$ radio frequency discharge plasma irradiation. Japanese Journal of Applied Physics, 51, 01 AE01.

KOSOUROV, S. N., GHIRARDI, M. L. \& SEIBERT, M. 2011. A truncated antenna mutant of Chlamydomonas reinhardtii can produce more hydrogen than the parental strain. International Journal of Hydrogen Energy, 36, 2044-2048.

LAROUSSI, M., MENDIS, D. A. \& ROSENBERG, M. 2003. Plasma interaction with microbes. New Journal of Physics, 5, 41.

LAWTON, L. A., ROBERTSON, P. K. J., ROBERTSON, R. F. \& BRUCE, F. G. 2003. The destruction of 2-methylisoborneol and geosmin using titanium dioxide photocatalysis. Applied Catalysis B: Environmental, 44, 9-13.

LEBOUT, H. 1959. Fifty Years of Ozonation at Nice. Ozone chemistry and technology. AMERICAN CHEMICAL SOCIETY.

LEMOINE, Y. \& SCHOEFS, B. 2010. Secondary ketocarotenoid astaxanthin biosynthesis in algae: a multifunctional response to stress. Photosynthesis Research, 106, 155-177.

LI, C., ZHAO, Y., SONG, H. \& LI, H. 2020a. A review on recent advances in catalytic combustion of chlorinated volatile organic compounds. Journal of Chemical Technology \& Biotechnology, 95, 2069-2082.

LI, J. X., SUN, C. J., ZHENG, L., JIANG, F. H., YIN, X. F., CHEN, J. H. \& WANG, X. R. 2016. Determination of lead species in algae by capillary electrophoresis-inductively coupled plasma-mass spectrometry. Chinese Journal of Analytical Chemistry, 44, 1659-1664.

LI, T., LI, H. \& LI, C. 2020b. A review and perspective of recent research in biological treatment applied in removal of chlorinated volatile organic compounds from waste air. Chemosphere, 250, 126338.

LI, X., LIU, R., LI, J., CHANG, M., LIU, Y., JIN, Q. \& WANG, X. 2015. Enhanced arachidonic acid production from Mortierella alpina combining atmospheric and room temperature plasma (ARTP) and diethyl sulfate treatments. Bioresource Technology, 177, 134-140.

LIN, K. C., LIN, Y. C. \& HSIAO, Y. H. 2014. Microwave plasma studies of Spirulina algae pyrolysis with relevance to hydrogen production. Energy, 64, 567-574.

LIN, Z., LI, J., LUAN, Y. \& DAI, W. 2020. Application of algae for heavy metal adsorption: A 20year meta-analysis. Ecotoxicology and Environmental Safety, 190, 110089.

LIU, B., SUN, Z., MA, X., YANG, B., JIANG, Y., WEI, D. \& CHEN, F. 2015. Mutation breeding of extracellular polysaccharide-producing microalga Crypthecodinium cohnii by a novel mutagenesis with atmospheric and room temperature plasma. International Journal of Molecular Sciences, 16, 8201-8212. 
LU, Y., SHANG, Y., HUANG, X., CHEN, A., YANG, Z., JIANG, Y., CAI, J., GU, W., QIAN, X., YANG, H. \& CHENG, R. 2011. Preparation of strong cationic chitosan-graftpolyacrylamide flocculants and their flocculating properties. Industrial \& Engineering Chemistry Research, 50, 7141-7149.

MAHAN, C. A., MAJIDI, V. \& HOLCOMBE, J. A. 1989. Evaluation of the metal uptake of several algae strains in a multicomponent matrix utilizing coupled plasma emission spectrometry. Analytical Chemistry, 61, 624-627.

MARTIN-JÉZÉQUEL, V., HILDEBRAND, M. \& BRZEZINSKI, M. A. 2000. Silicon metabolism in diatoms: implications for growth. Journal of Phycology, 36, 821-840.

MASMOUDI, S., NGUYEN-DEROCHE, N., CARUSO, A., AYADI, H., MORANT-MANCEAU, A., TREMBLIN, G., BERTRAND, M. \& SCHOEFS, B. 2013. Cadmium, copper, sodium and zinc effects on diatoms: from heaven to hell - a review,. Cryptogamie, Algologie, 34, 185223.

MIMOUNI, V., ULMANN, L., PASQUET, V., MATHIEU, M., PICOT, L., BOUGARAN, G., CADORET, J.-P., MORANT-MANCEAU, A. \& SCHOEFS, B. 2012. The potential of microalgae for the production of bioactive molecules of pharmaceutical interest. Current Pharmaceutical Biotechnology, 13, 2733-2750.

MITCHELL, P. G., GREENE, B. \& SNEDDON, J. 1986. Direct determination of mercury in solid algal cells by direct-current argon-plasma emission-spectrometry with sample introduction by electrothermal vaporization. Mikrochimica Acta, 1, 249-258.

MIZUKOSHI, Y., MATSUDA, Y., YAMANAKA, S., IKENO, T., HARAGUCHI, K., GODA, N., NISHIMURA, Y. \& YAMAMOTO, K. 2018. Deactivation of algae by plasma generated in seawater flow. Chemistry Letters, 47, 116-118.

MOSS, R., EDMONDS, J., HIBBARD, K., MANNING, M., ROSE, S., VUUREN, D., CARTER, T., EMORI, S., KAINUMA, M., KRAM, T., MEEHL, G., MITCHELL, J., NAKICENOVIC, N., RIAHI, K., SMITH, S., RONALD, S., THOMSON, A., WEYANT, J. \& WILBANKS, T. 2010. The next generation of scenarios for climate change research and assessment. Nature, 463, 747-756.

NGUYEN-DEROCHE, T. L. N. N., CARUSO, A., LE, T. T., VIET BUI, T., SCHOEFS, B., TREMBLIN, G. \& MORANT-MANCEAU, A. 2012. Zinc affects differently growth, photosynthesis, antioxidant enzyme activities and phytochelatin synthase expression of four marine diatoms. ScienceWorldJournal, 15, ID 982957.

NISOL, B., WATSON, S., LEBLANC, Y., MORADINEJAD, S., WERTHEIMER, M. R. \& ZAMYADI, A. 2019. Cold plasma oxidation of harmful algae and associated metabolite BMAA toxin in aqueous suspension. Plasma Processes and Polymers, 16, article number e1800137.

OEY, M., ROSS, I. L., STEPHENS, E., STEINBECK, J., WOLF, J., RADZUN, K. A., KÜGLER, J., RINGSMUTH, A. K., KRUSE, O. \& HANKAMER, B. 2013. RNAi knock-down of LHCBM1, 2 and 3 increases photosynthetic $\mathrm{H}_{2}$ production efficiency of the green alga Chlamydomonas reinhardtii. Plos ONE, 8, e61375.

OKADA, T., CHANG, C.-Y., KOBAYASHI, M., SHIMIZU, T., SASAKI, M. \& KUMAGAI, S. 2016. Plasma-on-chip device for stable irradiation of cells cultured in media with a lowtemperature atmospheric pressure plasma. Archives of Biochemistry and Biophysics, $605,11-18$.

PAERL, H. W. \& PAUL, V. J. 2012. Climate change: links to global expansion of harmful cyanobacteria. Water Research, 46, 1349-1363.

PARKER, M. S., MOCK, T. \& ARMBRUST, E. V. 2008. Genomic insights into marine microalgae. Annual Review of Genetics, 42, 619-645.

PUGAZHENDHI, A., SHOBANA, S., BAKONYI, P., NEMESTÓTHY, N., XIA, A., BANU J, R. \& KUMAR, G. 2019. A review on chemical mechanism of microalgae flocculation via polymers. Biotechnology Reports, 21, e00302. 
RASHID, N., REHMAN, S. U. \& HAN, J.-I. 2013. Rapid harvesting of freshwater microalgae using chitosan. Process Biochemistry, 48, 1107-1110.

ROHÁČEK, K., BERTRAND, M., MOREAU, B., JACQUETTE, J., CAPLAT, C., MORANTMANCEAU, A. \& SCHOEFS, B. 2014. Relaxation of the non-photochemical chlorophyll fluorescence quenching in diatoms: kinetics, components and mechanisms.

Philosophical Transactions of the Royal Society B: Biological Sciences, 369, 20130241.

RUSANOV, V. D., FRIDMAN, A. A. \& SHOLIN, G. V. 1981. The physics of a chemically active plasma with nonequilibrium vibrational excitation of molecules. Soviet Physics Uspekhi, 24, 447-474.

SALGADO, S. G., NIETO, M. A. Q. \& SIMON, M. M. B. 2006. Determination of soluble toxic arsenic species in alga samples by microwave-assisted extraction and high performance liquid chromatography-hydride generation-inductively coupled plasma-atomic emission spectrometry. Journal of Chromatography A, 1129, 54-60.

SAXENA, A., PRAKASH, K., PHOGAT, S., SINGH, P. K. \& TIWARI, A. 2020. Inductively coupled plasma nanosilica based growth method for enhanced biomass production in marine diatom algae. Bioresource Technology, 314.

SCARSINI, M., MARCHAND, J. \& SCHOEFS, B. 2020. Carotenoid overproduction in microalgae: Biochemical and genetic engineering. In: JACOB-LOPES, E., QUEIROZ, M. I. \& ZEPKA, L. Q. (eds.) Pigments from Microalgae Handbook. Cham: Springer International Publishing.

SCHIAVON, M., TORRETTA, V., CASAZZA, A. \& RAGAZZI, M. 2017. Non-thermal plasma as an innovative option for the abatement of volatile organic compounds: A review. Water, Air, \& Soil Pollution, 228, 388.

SCHOEFS, B. 2003. Chlorophyll and carotenoid analysis in food products. A practical case-bycase view. Trends in Analytical Chemistry, 22, 335-339.

SCHOEFS, B. 2004. Determination of pigments in vegetables. Journal of Chromatography A, 1054, 217-226.

SCHOEFS, B., VAN DE VIJVER, B., WETZEL, C. \& ECTOR, L. 2020. From diatom species identification to ecological and biotechnological applications. Botany Letters, 167, 2-6.

SHEN, X., ZHANG, H. T., HE, X. L., SHI, H. L., STEPHAN, C., JIANG, H., WAN, C. H. \& EICHHOLZ, T. 2019. Evaluating the treatment effectiveness of copper-based algaecides on toxic algae Microcystis aeruginosa using single cell-inductively coupled plasma-mass spectrometry. Analytical and Bioanalytical Chemistry, 411, 5531-5543.

SINGH, M., SHUKLA, R. \& DAS, K. C. 2013. Harvesting of microalgal biomass. In: BUX, F. (ed.) Biotechnological Applications of Microalgae: Biodiesel and Value Added Products. Taylor and Francis Group.

STRAŇÁK, V., ŠPATENKA, P., TICHÝ, M., KOLLER, J., KŘÍHA, V. \& SCHOLTZ, V. 2006. Surfatron plasma-based sterilisation. Czechoslovak Journal of Physics, 56, B843-B847.

SUN, Y. J., REN, M. J., SUN, W. Q., XIAO, X. F., XU, Y. H., ZHENG, H. L., WU, H. F., LIU, Z. Y. \& ZHU, H. 2019. Plasma-induced synthesis of chitosan-g-polyacrylamide and its flocculation performance for algae removal. Environmental Technology, 40, 954-968.

SUN, Y. J., ZHU, C. Y., SUN, W. Q., XU, Y. H., XIAO, X. F., ZHENG, H. L., WU, H. F. \& LIU, C. Y. 2017. Plasma-initiated polymerization of chitosan-based CS-g-P(AM-DMDAAC) flocculant for the enhanced flocculation of low-algal-turbidity water. Carbohydrate Polymers, 164, 222-232.

TANG, Y. Z., LU, X. P., LAROUSSI, M. \& DOBBS, F. C. 2008. Sublethal and killing effects of atmospheric-pressure, nonthermal plasma on eukaryotic microalgae in aqueous media. Plasma Processes and Polymers, 5, 552-558.

TARRADE, J., DARMANIN, T., TAFFIN DE GIVENCHY, E., GUITTARD, F., DEBARNOT, D. \& PONCIN-EPAILLARD, F. 2014. Texturation and superhydrophobicity of polyethylene terephthalate thanks to plasma technology. Applied Surface Science, 292, 782-789. 
THAKUR, V. K. \& THAKUR, M. K. 2014. Recent advances in graft copolymerization and applications of chitosan: A review. ACS Sustainable Chemistry \& Engineering, 2, 26372652.

TSAI, W. T. 2017. Fate of chloromethanes in the atmospheric environment: Implications for human health, ozone formation and depletion, and global warming impacts. Toxics, 5, 23.

VERHELST, S. \& WALLNER, T. 2009. Hydrogen-fueled internal combustion engines. Progress in Energy and Combustion Science, 35, 490-527.

VINAYAK, V., MANOYLOV, K. M., GATEAU, H., BLANCKAERT, V., HERAULT, J., PENCREAC'H, G., MARCHAND, J., GORDON, R. \& SCHOEFS, B. 2015. Diatom milking: a review and new approaches. Marine Drugs, 13, 2629-2665.

WANG, J.-P., CHEN, Y.-Z., GE, X.-W. \& YU, H.-Q. 2007. Gamma radiation-induced grafting of a cationic monomer onto chitosan as a flocculant. Chemosphere, 66, 1752-1757.

WANG, J.-P., CHEN, Y.-Z., ZHANG, S.-J. \& YU, H.-Q. 2008. A chitosan-based flocculant prepared with gamma-irradiation-induced grafting. Bioresource Technology, 99, 33973402.

WANG, L. Y., HUANG, Z. L., LI, G., ZHAO, H. X., XING, X. H., SUN, W. T., LI, H. P., GOU, Z. X. \& BAO, C. Y. 2010. Novel mutation breeding method for Streptomyces avermitilis using an atmospheric pressure glow discharge plasma. Journal of Applied Microbiology, 108, 851-858.

WANG, M., YANG, Y., CHEN, Z., CHEN, Y., WEN, Y. \& CHEN, B. 2016. Removal of nutrients from undiluted anaerobically treated piggery wastewater by improved microalgae. Bioresource Technology, 222, 130-138.

XU, Z. 2014. Recent progress on atmospheric and room temperature plasma mutation breeding technology and its applications. CIESC Journal, 65, 2676-2684.

YE, J.-X., LIN, T.-H., HU, J.-T., POUDEL, R., CHENG, Z.-W., ZHANG, S.-H., CHEN, J.-M. \& CHEN, D.-Z. 2019. Enhancing chlorobenzene biodegradation by Delftia tsuruhatensis using a water-silicone oil biphasic system. International Journal of Environmental Research and Public Health, 16, 1629.

YU, J., GEGE, Y., YUANPEI, P., QUANFANG, L., WU, Y. \& JINZHANG, G. 2014. Poly (acrylamide-co-acrylic acid) hydrogel induced by glow-discharge electrolysis plasma and its adsorption properties for cationic dyes. Plasma Science and Technology, 16, 767.

ZAMYADI, A., MCQUAID, N., DORNER, S., BIRD, D., BURCH, M., BAKER, P., HOBSON, P. \& PREVOST, M. 2012. Cyanobacterial detection using in vivo fluorescence probes: Managing interferences for improved decision-making. Journal of the American Water Works Association, 104, E466-E479.

ZHANG, H., HUANG, Q., KE, Z., YANG, L., WANG, X. \& YU, Z. 2012. Degradation of microcystin-LR in water by glow discharge plasma oxidation at the gas-solution interface and its safety evaluation. Water Research, 46, 6554-6562.

ZHANG, Y., HE, M., ZOU, S., FEI, C., YAN, Y., ZHENG, S., RAJPER, A. A. \& WANG, C. 2016. Breeding of high biomass and lipid producing Desmodesmus sp. by ethylmethane sulfonate-induced mutation. Bioresource Technology, 207, 268-275. 